\title{
Merging Engineering Education with Service- Learning: How Community Based Projects Encourage Socially Conscious Engineers
}

\author{
By Aaron Brown ${ }^{*} \&$ Michael Bauer ${ }^{\dagger}$
}

\begin{abstract}
Engineers provide essential services to society, solving pressing challenges through technological inventiveness. Students new to engineering often cite the lure of creative problem solving as attracting them to the discipline. However, traditional engineering curricula typically focus on a narrow application of fundamentals for solving closed-ended problems. Too often, engineering programs do not encourage inventive expression in problem solving. Not surprisingly, the attrition rate for engineering programs is unusually high. Recently, engineering education has shifted its focus to new, more engaging practices that incorporate hands-on methods, boosting prospects for students to engage in creative problem solving. Because service learning provides opportunities for applied work, incorporating it into engineering education programs in can engage students positively and lower attrition rates. Moreover, since engineers are fundamentally involved with social improvement, then engaging students in activities that expand their understanding of the potential impact their skills may impart to a community is not only prudent but best practices. This paper explores two case studies of community-based service learning engineering projects, highlighting community partnerships, analyses and decision-making that helped drive designs and outcomes. It explores how both the communities and students benefitted, focusing notably on the influence these activities had on student understanding of their work, academic and/or professional direction and social consciousness. These are analyzed via longitudinal reporting of students incorporating lessons learned several years post-project. The service learning projects took place in marginalized communities in Denver and Costa Rica. In the Denver project, engineering students designed, built and installed low cost solar heaters into an area with poor housing stock. In Costa Rica, students built a solar water heater for a local school.
\end{abstract}

Keywords: applied learning, engineering education, experiential learning, service-learning.

\section{Introduction}

Engineering is a discipline with service as a core attribute of the profession: service to community, and society (Lucena, 2013; Layton, 1986). Engineers employ technological inventiveness to solve pressing challenges. In fact, neophytes often cite the potential for creative problem solving as an attractive lure to pursue

*Professor, Metropolitan State University of Denver, USA.

${ }^{\dagger}$ Director of Sustainability, Naropa University, USA. 
an education in engineering (Besterfield-Sacre, Atman, \& Shuman, 1997; Matusovich, Streveler, \& Miller, 2013). However, traditional engineering curricula typically focus on narrowly applying theory and fundamentals to solve sanitized, closed-ended problems. If engineering programs do not encourage inventive, inclusive expression in problem solving, they risk severing connections between theory and practice and between student and society. This relative disconnect contributes to an unusually high student attrition rate in those engineering programs (Astin, 1993; Moller \& Eide, 1997; Besterfield-Sacre, Atman, \& Shuman, 1997; Litzinger, Lattuca, \& Hadgraft, 2011; Marra, Rodgers, Shen, \& Bogue, 2012).

Recently, engineering education professionals have advocated shifting their focus to incorporate more community opportunities that engage students directly in creative problem solving through practical application. Service-learning projects can provide opportunities that fit these criteria. Therefore, infusing engineering curricula with service-learning programs can actively involve students and thereby lower attrition rates (Budny \& Gradoville, 2011) (Coyle, Jamieson, \& Oakes, 2005; Moskal, Skokan, Muñoz, \& Gosink, 2008). Moreover, since engineers are fundamentally involved with social improvement, then immersing students in service-learning activities that clearly display the impact of their skills on a community is not only prudent, but best practices (Litchfield, Javernick-Will, \& Maul, 2015).

Considering this ideology, the following paper shares evidence that indicate how one engineering program benefited from imbuing its curricula with servicelearning opportunities. This paper explores two case studies of community-based service-learning engineering projects, and in so doing, discusses community partnerships, analyses and the decisions that drove project designs and outcomes. It explores how both the communities and students benefitted, focusing notably on the influence these activities had on student understanding of their work, any changes in academic or professional direction, and shifts in social consciousness. These are analyzed via longitudinal reporting of students incorporating lessons learned into their present lives and careers, several years post-project. The servicelearning community projects examined are as follows:

- Solar Water Heater in Costa Rica: engineering students built a solar water heater for a local school.

- Solar Air Heaters in Denver: engineering students designed, built and installed low cost solar heaters into an impoverished and marginalized community.

\section{Concepts}

The current state of the practice loosely characterizes Service Learning, its definition encompassing a variety of educational experiences. For example, the spectrum of descriptions includes volunteerism, community service, field studies, and internships (Furco, 1996). With a historically nebulous identity, incorporating the term "service learning" may confuse the reader. As such, in this study service learning is defined as an educational approach that combines applied action with outcomes that benefit a partner community. 
Social Consciousness is also a term that has been loosely characterized in the literature. The most commonly used definition has been put forth by Ammetorp (2007) who identified it as a "process involving increasing awareness of social historical context, the ability to think abstractly about time and place, and beyond the immediate everyday conditions to understand individual experience as embedded in a broader system of social relations" (p. 39). For the context of this paper, we elaborate as follows: a developed social consciousness is a developed awareness of the impact one might have on the social system in which one is immersed.

In the present context, Educational Experience refers to students' contact with the process by which the described learning and development occurs.

\section{Background}

Attrition rates for engineering students are high (Astin 1993; Moller-Wong \& Eide 1997; Besterfield-Sacre, Atman, \& Shuman, 1997; Bransford, Brown, \& Cocking, 1999; Litzinger, Lattuca, \& Hadgraft, 2011; Marra, Rodgers, Shen, \& Bogue, 2013; Godfrey, Aubrey, \& King, 2010; Litzler \& Young, 2013; Geisinger \& Raman, 2013). Service learning can ameliorate this problem (Litzinger, Lattuca, \& Hadgraft, 2011; Marra, Rodgers, Shen, \& Bogue, 2013; Litchfield, JavernickWill, \& Maul, 2015; Budny \& Gradoville, 2011; Moskal, Skokan, Munoz, \& Gosink, 2008), so the question becomes how best to suffuse engineering programs with appropriate, meaningful service-learning projects.

At Metropolitan State University of Denver (MSU Denver), the author launched a humanitarian engineering club to engage students in activities that benefit marginalized communities (Brown, 2015). Since its inception in 2009, the club has recruited on average 11 new students each semester. Metropolitan State University of Denver has an office of Applied Learning, which includes a servicelearning program. Students can earn certificates from this program in service learning by taking designated courses. Because MSU Denver is a strong advocate of the philosophy of Service-Learning, by natural extension the during recruitment efforts for the Humanitarian Engineering Club, the service-learning aspect of the club is heavily emphasized, with recent development projects highlighted at meetings and class presentations. In addition to the club, the Department of Engineering and Engineering Technology have created two service-learning courses. The courses, "Humanitarian Engineering" and "Design Experience" use the humanitarian engineering student club as a recruiting tool. Each semester, a sustainable community development project is identified which might be incorporated into the described courses and/or a student club activity. In approaching the projects, students are introduced to an analysis structure following the CARE model (Caldwell, 2002). This methodology guides project diagnosis through a methodical manner. This approach is systematic and holistic in its nature. The concept is to engage the involved community in a participatory identification of their issues. Students then direct diagnoses toward 1) the fundamental causes of these issues, and 2) approaching them an appropriate way that builds capacity for the community. The following diagram was borrowed 
from Caldwell's handbook, highlighting the interrelationships among the methodological components.

Figure 1. Project Design Frame Work

\section{CARE's project design framework}

2. Analysis and Synthesis

Purpose - Organizing, synthesizing and

understanding the data from your appraisal

Key steps/Tools:

- System perspective

- Cause-effect logic in project design

- Hienarchical analysis

- Methods of causal analysis

- Macra-micro linkages

Key Steps/Tools:

- Operating environment

- Diagnostics

- Target groups

- Understanding diversity

- Stokeholder analysis

- Institutional asses

- Gender analysis

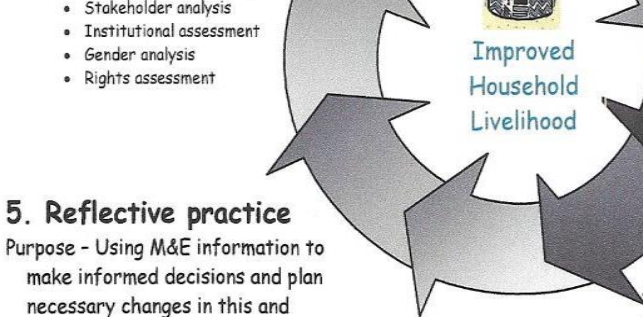

necessary changes in this and

future projects

Key steps/Tools:

- Incorporating reflective practice in

design

- Intended/unintended changes

- Benefits/harms analysis

by gender on wolmerable groups, e.g.

- Insturion, poverty status

- Change management

Source: CARE

Additionally, students learn the concept of "appropriate technology" (Hazeltine \& Bull, 1999; Schumacher, 1973) and how this philosophy might improve projects in the partner community. At the conclusion of each service-learning project, participating students are surveyed on the impact their projects had on their attitudes and beliefs. Additionally, the students involved in these projects were surveyed several years post-project (in most cases post-graduation) for longitudinal analysis, and to ascertain any influence the experiences may have had on their career paths. Additionally, the authors collected data on graduation rates of the students involved vs. rates in the larger engineering program.

Costa Rica Hot Water Heater. In the winter interim term of 2014 (called "Winterim"), twelve students took part in the first edition of the "Humanitarian Engineering" course (described above). In this edition of the course students traveled to Costa Rica where they participated in an engineering project for a small school in an impoverished rural community. Employing the CARE analysis technique (Caldwell, 2002), students identified a solar hot water heater as one appropriate technology that might benefit the school and was reasonable to tackle and within the time frame of the class. The students designed and built a very simple solar hot water heater using locally available materials. Testing showed 
their design to be effective and so, in collaboration with the beneficiary community, the new unit was installed at the school.

Denver Solar Air Heaters. While the aforementioned project took part in a developing community in a developing country, impoverished communities located in wealthy industrialized countries still face the constraining effects of ill health, fewer education opportunities and economic isolation. These burdens interrelate in such a way that services and technologies in nearby wealthier communities, although available, remain financially inaccessible.

The community of Westwood in Denver, Colorado is an example of a community faced with the marginalizing forced described above. Westwood is vulnerable to risks in a variety of domains: economic, social, cultural, health, safety and education (Brown, Teipel, Litchfield, Gilmore, 2014). However, Westwood is not without community resources. ReVision ${ }^{1}$ is a non-profit organization located in Westwood whose mission is to "educate, inspire, connect, and empower individuals and communities to achieve change through locally created, scalable models." Westwood possesses the capacity to mitigate vulnerabilities, and targeted intervention can augment that capacity.

Graduate engineering students in the Sustainable Community Development class at the University of Colorado partnered with ReVision in Westwood to conduct a community appraisal, problem identification and technological intervention. During the community appraisal phase, residents of Westwood cited significant health and safety concerns around housing quality. Due to local income levels and neighborhood vintage, many houses were in poor repair and had inadequate insulation and inefficient heating systems, leading to high winter heating costs (Brown, 2015). During the problem identification phase residents revealed that high household energy costs were a problem, and that Westwood possesses the capacity to mitigate them (Bauer, 2014). At length, it was agreed that introducing solar furnace technology to the community could alleviate household heating expenses (Wojke, 2005; Smith, 2003).

The aluminum can solar air heater is not an original technology. The furnaces proposed here are similar in design to others already in use around the world. However, a detailed literature review found no studies where practitioners implemented this very simple and sustainable technology into a marginalized community to mitigate high household energy expenses or indoor air quality issues (McKenzie-Moore \& Smith, 2010; Smith, 2003; Brown, 2015).

In Westwood, 10 students from the MSU Denver Humanitarian Engineering Club and the Design Experience class continued the work started by the University of Colorado graduate students. The data suggested that the soda can solar furnace might be an appropriate technology to introduce into the community, so the club members designed and constructed several additional models. After testing these models for performance, students installed several units into the community at households recruited by ReVision (Cotton, 2014). After several months, the students followed up with monitoring and evaluation to access the impact and success of the project for the involved households. In addition, as word spread in

\footnotetext{
${ }^{1}$ http://www.revisioninternational.org.
} 
the neighborhood about the benefits of the project, the students leveraged the community interest in the helpfulness of this technology to host a workshop in which they taught community members how to construct their own heaters with locally available supplies (Brown, 2015).

\section{Methods}

Upon completion of the service learning projects/class, the authors surveyed the participating MSU Denver Engineering students. The survey instrument is designed to measure the influence of service-learning work on students' perspectives about engineering, their career interests, and social consciousness. This questionnaire borrows some from the American Association of Community Colleges "Student Service Learning Survey" (Carberry, Lee, \& Swan, 2013) in conjunction with questions more specific to engineering service-learning. It is of mixed quantitative and qualitative methodology, including open-ended questions and discrete analysis. This correlates roughly to Ball and Lampert's (1999) "multiples of time, evidence, and perspective," methodology.

Appendix A presents the complete survey instrument. Appendix B shows the survey from 2015-16, several years post-project. Results from both aforementioned student experiences are pooled for analysis.

As seen in Appendix A, qualitative data are collected via open-ended questions regarding students' attitudes about engineering as a service profession, their career goals and their social consciousness; these data are collected, coded and analyzed. Quantitative data are collected via student enrollment rates, project participation and attrition rates in annual humanitarian engineering projects: community appraisal, design process, technology manufacture and community intervention.

\section{Results}

\section{Initial Survey Indicators}

Adjectival responses were converted to numerical scores for analysis. The results from the initial post-project surveys $(\mathrm{N}=22)$ strongly indicate that the service-learning experience enhanced their educational experience, social consciousness of engineering as a discipline that serves society, and general interest in engineering. Survey questions were grouped by theme: Educational Experience, Social Consciousness and Curriculum Comprehension and Application.

Educational Experience: Combined Score $=$ 344/352. Survey questions 4 , $5,7,12$, and 13 relate to the influence of service-learning projects on educational experience. Total survey score ranges from 88 (negative or no influence on students' educational experience) to 352 (positive experience, motivating for the 
student). The combined score reported for these questions was 344, indicating a strongly positive or beneficial effect on the education experience.

Social Consciousness: Combined Score $=\mathbf{4 8 4 / 5 2 8}$. Questions 1, 2, 3, 9, 10 and 11 related to the courses' influence on students' social consciousness. The combined reported score recorded in this category was 484 , which is $92 \%$ of the maximum possible, strongly indicating that social consciousness was enhanced by participation in these activities.

Curriculum Comprehension and Application: Combined Score=393/440. Survey questions 4, 5, 7, 8 and14 measured how the service-learning experience influenced student's understanding of the curriculum and its real-world applications. Scoring in this category ranges from 110 (negative or no influence on material comprehension through application) to 440 (strong improvement of material comprehension through application). The combined reported score was 393 or $89 \%$ of the maximum. This reveals that the service-learning project enhanced understanding of the material.

Finally, Question 6 asks respondents if they intend to continue community service upon completion of the course. Scoring for this question ranged from 88students do not intend to continue any further community service activities - to 22 - students strongly intend to continue community service work in the future. Results for this metric were mixed, with a score of 29 or about $75 \%$ of the strongest value. Of note, one student included the response:

"I would (continue community service) if there was another class".

Question 15. This was my first service-learning experience. All but one of the students responded that this was their first service-learning experience.

Question 16. How do you see engineering as a service tool for society? Some students indicated understanding that engineering was a service profession, and that the course revealed practical applications for their skills to help others. To this point, the following responses to question 16 was recorded.

- "Engineering can help people. Sometimes it's easy ideas that help."

- "This class helped me see how I can make a difference for others."

- "Engineers solve problems. Poorer people have more problems that need solutions."

Question 17. Describe how this service-oriented project benefitted you. For Question 17, 100\% of respondents indicated that they benefitted from the service-learning aspect of the courses. Below are some examples of their recorded responses.

"When the little boy felt the heat from our furnace in his room and said 'I'm gonna sleep so well now because it's so warm in here now' that was all I had to hear. I knew I made a difference." 
"I never realized how well I had it and that there were people living in such hard conditions not so far away. Also, this helped me realize that I can help people less fortunate then me."

"I enjoyed the hands-on aspect of creating something that was actually going to be used."

Longitudinal Survey Results and Student Retention. Of the 22 students who participated in service-learning projects, all but two have graduated from the engineering program.

Of those two, one switched academic majors to math education and has graduated and gone on to receive a master's degree in engineering with a focus on Engineering for Developing Communities; the other student has withdrawn from school, but intends to return at "some point". The retention percentage for those taking part in these experiences, then, are approximately 95\%. While this sample size is small, compared to the department-wide program retention rate of approximately $48 \%$, this is a considerable increase.

Eighteen of the original 22 participants were contacted for the follow-up survey. Of those 18, 17 and are currently employed, and 10 participants indicated that the experience influenced their career choices. To wit, the following are representative of student responses:

"I got a job building micro-satellites. It's a neat company to work for and since it's smaller, I can actually have a large impact. We recently provided imagery to Nepal for evacuation purposes after the earthquakes so it's nice the company has a humanitarian component as well. I got the job because of my experience in the humanitarian engineering class."

"I never realized there could be a social-justice component in engineering. I have an interest in getting my master's, and possibly a doctorate related to this kind of work".

All of the participants in the survey indicated they benefitted from the servicelearning experience.

\section{Discussion}

As in all social inquiries, the data are subject to limitations. One can interpret these findings with respect to several common sampling biases.

\section{Response Bias}

Some respondents will tend to answer survey questions misleadingly or without the full truth. This is called "Response Bias" or "Survey Bias." As an example, participating engineering students may feel obligated or otherwise pressured to answer the questions in a "socially acceptable" way because question syntax or the recent survey theme may influence the student to sway his or her 
response. Response bias is common on self-reporting surveys, especially with respect to issues of personal traits and attitudes.

\section{Self-Selection Bias}

When individuals choose to join a group, they in effect select themselves into that group, inducing a biased sample population with nonprobability sampling. This is "Self-Selection Bias", which occurs when individuals in a group already contain characteristics, demographics or beliefs not held by a larger sample of "others" outside the group. In this way, respondents have motivations that bias their data, making determination of causation more difficult. For example, there may be a numerous and varied differences between those in the Humanitarian Engineering Club at MSU Denver University of Colorado (such as socioeconomic status or motivation), that are not found in students outside the group.

\section{Conclusion}

The evidence of this study tends to indicate that the service-learning projects benefited the engineering students involved. Participants in the aforementioned service-learning activities provided responses in surveys that demonstrated improved understanding of engineering as a profession that can serve society, broader social awareness and furthermore implied that the project influenced future trajectory to engage in service activities. The retention rate for the students in these activities was significantly higher than students' peers in the larger engineering program. Longitudinal inquiry also suggested that the service-learning experiences encouraged a professional direction that involved work to help others for some students.

\section{References}

Astin, A. (1993). What matters in college: four critical years revisited. San Francisco, CA, USA: Jossey-Bass.

Ammentorp, L. (2007). Imagining social change: Developing social consciousness in an arts-based pedagogy. Outlines. Critical Practice Studies, 9(1), 38-52. Retrieved from https://bit.ly/2oZNY0j.

Ball, D.L., \& Lampert, M., (1999). Multiples of evi-dence, time and perspective: Revising the study of teaching and learning. In E. Comdliffe Lagemann \& L. S. Shulman (Eds), Issues in Education Reseacrh: Problems and Possibilities. San Francsico: Jossey-Bass

Bauer, A., Brown, A. (2014). Quantitative assessment of appropriate technology: Decision support for sustainable community development. Procedia Engineering, 78(2014), 345-358.

Besterfield-Sacre, M., Atman, C., \& Shuman, L. (1997). Characteristics of Freshman Engineering Students: Models for Determining Student Attrition in Engineering. Journal of Engineering Education, 86(2), 139-149. 
Bransford, J. D., Brown, A. L., \& Cocking, R. (eds.) (1999). How people learn: brain, mind, experience, and school. Washington, DC, USA: National Academies Press.

Brown, A., Teipel, E., Litchfield, L., Gilmore, L. (2014). Sustainable community development project: Westwood solar furnace project. IEE Xplore Global Humanitarian Technology Conference (GHTC) (3), 421-425

Budny, D., \& Gradoville, R.T. (2011). International Service-learning design projects: educating tomorrow's engineers, servicing the global community and helping to meet ABET criteria. International Journal for Service-Learning in Engineering, 6(2), 98117.

Brown, A. (2015). Community Adoption of appropriate technology through persuasive communication design. Doctoral Dissertation. Boulder, CO, USA: University of Colorado at Boulder.

Caldwell, R. (2002). Project Design Handbook. Atlanta: Cooperative for Assistance and Relief Everwhere, Inc. (CARE).

Carberry, A.R., Lee, H.-S., \& Swan, C. (2013). Student perceptions of engineering service experiences as a source of learning technical and professional skills. International Journal for Service Learning in Engineering, Humanitarian Engineering and Social Entrepeneurship, 8(1), 1-17.

Cotton, A. (2014, January 9). Soda-can furnaces powered by solar energy heat Denver neighborhood. The Denver Post.

Coyle, E., Jamieson, L. H., \& Oakes, W.C. (2005). EPICS: Engineering projects in community service. International Journal of Engineering Education, 21(1), 139-150.

Furco, A. (1996). Service-learning: A balanced approach to experiential education. Service Learning, General, 128, 2-6.

Geisinger, B. N., \& Raman, D. R. (2013). Why they leave: Understanding student attrition from engineering majors. Iowa, USA: Agricultural Hazeltine, B., \& Bull, C. (1999). Appropriate Technology: Tools Choices and Implications. Academic Press.

and Biosystems Engineering Publications.

Godfrey, E., Aubrey, T., \& King, R. (2010). Who leaves and who stays? Retention and Attrition in Engineering Education. Journal of Engineering Education, 5(2), 26-40.

Layton, E. T. (1986). The revolt of engineers. Social responsibility and the american engineering profession. Baltimore, MD, USA: Johns Hopkins University Press.

Litchfield, K., Javernick-Will, A., \& Maul, A. (2015). Technical and professional skills of engineers involved and not involved in engineering service. Journal of Engineering Education, 105(1), 70-92.

Litzinger, T., Lattuca, L., \& Hadgraft, R. (2011). Engineering Education and the Development of Expertise. Journal of Engineering Education, 100(1), 123-150.

Litzler, E. \& Young, J. (2013). Understanding the risk of attrition in undergraduate engineering: results from the project to assess climate in engineering. Journal of Engineering Education, 101(2), 319-345.

Lucena, J. (ed.) (2013). Engineering education for social justice. Engineering Education for Social Justice: Critical Explorations and Opportunities. London; Springer.

Marra, R., Rodgers, K., Shen, D., \& Bogue, B. (2013). Leaving Engineering: A MultiYear Single Institution Study. Journal of Engineering Education, 101(1), 6-27.

Matusovich, H.M., Streveler, R., \& Miller, S. (2013). Why do students choose engineering? A qualitative longitudinal study investigation of students' motivational values. Journal of Engineering Education, 99(4), 289-303.

McKenzie-Moore, D., \& Smith, W. (2010). Community-based social marketing: Fostering sustainable behavior. Retrieved from: https://bit.ly/2Pi1erw 
Moskal, B. M., Skokan, C., Muñoz, D., \& Gosink, J. (2008). Humanitarian Engineering: Global Impacts and Sustainability of a Curricular Effort. International Journal of Engineering Education, 24(1), 162-174.

Moller, C., \& Eide, A. (1997). An Engineering Student Retention Study. Journal of Engineering Education, 86(1), 7-15.

Schumacher, E. (1973). Small is Beautiful - A Study of Economics as if People Mattered. London, UK: Blond \& Briggs.

Smith, K. R. (2003). Indoor Air Pollution. at a glance Washington, DC: World Bank. Retrieved from https://bit.ly/32ITYJi.

Wojke, A. (2005). A review of intervention studies aimed at household energy conservation. Journal of Environmental Psychology, 25, 273-291. 


\section{Appendix A}

\section{Questionnaire for Service-Learning Participation}

Please respond as honestly as possible, relying on your current beliefs or attitudes toward the particular issues raised. Indicate your level of agreement with each statement by circling the appropriate choice.

\begin{tabular}{|l|c|c|c|c|}
\hline & $\begin{array}{c}\text { Strongly } \\
\text { Agree }\end{array}$ & Agree & Disagree & $\begin{array}{c}\text { Strongly } \\
\text { Disagree }\end{array}$ \\
\hline $\begin{array}{l}\text { 1. I have a good understanding of the needs and } \\
\text { problems facing the community in which the project } \\
\text { took place. }\end{array}$ & 4 & 3 & 2 & 1 \\
\hline $\begin{array}{l}\text { 2. If everyone works together, many of society's } \\
\text { problems can be solved. }\end{array}$ & 4 & 3 & 2 & 1 \\
\hline $\begin{array}{l}\text { 3. I have a responsibility to serve society. } \\
\begin{array}{l}\text { 4. I learn course content best when connections to real- } \\
\text { life situations are made. }\end{array}\end{array}$ & 4 & 3 & 2 & 1 \\
\hline $\begin{array}{l}\text { 5. The idea of combining course work with service to } \\
\text { the community should be practiced in more courses at } \\
\text { this university. }\end{array}$ & 4 & 3 & 2 & 1 \\
\hline $\begin{array}{l}\text { 6. I probably won't volunteer or participate in } \\
\text { community service after this course ends. }\end{array}$ & 4 & 3 & 2 & 1 \\
\hline $\begin{array}{l}\text { 7. The service aspect of this course helped me to } \\
\text { understand better the required lectures and readings. }\end{array}$ & 4 & 3 & 2 & 1 \\
\hline $\begin{array}{l}\text { 8. The service aspect of this course helped me to see } \\
\text { how the subject matter I learned can be used in } \\
\text { everyday life. }\end{array}$ & 4 & 3 & 2 & 1 \\
\hline $\begin{array}{l}\text { 9. The service aspect of this course made me aware of } \\
\text { some of my own biases or prejudices. }\end{array}$ & 4 & 3 & 2 & 1 \\
\hline $\begin{array}{l}\text { 10. The service aspect of this course showed me how I } \\
\text { can become more involved in my community. }\end{array}$ & 4 & 3 & 2 & 1 \\
\hline $\begin{array}{l}\text { 11. As a result of my service learning experience, I have } \\
\text { a better understanding of my role as a citizen. }\end{array}$ & 4 & 3 & 2 & 1 \\
\hline $\begin{array}{l}\text { 12. I plan to enroll in more courses that offer service } \\
\text { learning. }\end{array}$ & 4 & 3 & 2 & 1 \\
\hline $\begin{array}{l}\text { 13. As a result of my service learning experience, I } \\
\text { would encourage other students to take courses that } \\
\text { offer service learning. }\end{array}$ & 4 & 3 & 2 & 1 \\
\hline $\begin{array}{l}\text { 14. The agency/site provided challenging, meaningful, } \\
\text { and educational tasks for me to accomplish. }\end{array}$ & 4 & 3 & 2 & 1 \\
\hline
\end{tabular}

15. This was my first service learning experience. (Please circle the appropriate response)
a. Yes
b. No

16. How do you see engineering as a service tool for society?

17. Describe how this service oriented project benefitted you: 


\section{Appendix B}

\section{Survey 2: Longitudinal Survey}

1. Are you:
a. still enrolled in engineering program
b. graduated from engineering program
c. enrolled in another program (non-engineering)
d. graduated from another program (non-engineering)
e. not completed school and not enrolled currently

2. If you are no longer a student what career /job do you currently have?

3. Did your service-learning experience have an influence on your career choice and if $s$ can you describe how?

4. Who do you feel from your service-learning experience?
a. benefitted
b. not benefit
c. neither a nor $b$

5. Do you now or plan to continue to do work outside of your job responsibilities that offer service to others? 
